\title{
Laju Pertumbuhan dan Hasil Kubis Bunga Akibat Perlakuan Pupuk Organik Cair
}

\section{Growth Rate and Yield of Cauliflower Due to Liquid Organic Fertilizer Treatment}

\author{
Edy Kustiani ${ }^{1}$, Supandji ${ }^{2}$, Adib Adiana ${ }^{3}$ \\ ${ }^{1,2,3}$ Program Studi Agroteknologi, Fakultas Pertanian, Universitas Kadiri \\ edykustiani88@unik-kediri.ac.id
}

Article Submitted : 06-10-2021

Article Accepted : 22-12-2021

\begin{abstract}
The people in Indonesia widely know cauliflower plants. In addition to their delicious taste, they also contain a high nutritional value for various kinds of dishes, both in restaurants and families. The purpose of this study was to determine the appropriate dose of liquid organic fertilizer (LOF) in order to obtain maximum growth and production of cauliflower (Brassica olerasea var Botritis). The study was conducted at the greenhouse of the Agriculture Faculty of Kadiri University. The experimental design employed a Completely Randomized Design (CRD), which consisted of six treatments repeated four times with a level test using the 5\% Least Significant Difference test. Based on the results of observations and data analysis, it was found that the LOF dose treatment had no significant effect on the parameters of the average plant height, the number of leaves, and leaf area at the age of 9 days after planting (DAP). However, there was a highly significant difference in the observations of the average plant height, number of leaves and leaf area at the age of 16, 23 and 30 DAP. The average plant height, number of leaves, and leaf area were the largest in the D3 treatment (LOF dose of $75 \mathrm{ml} /$ plant). The observation of root wet-weight, root dry-weight, plant wet-weight, plant dryweight, flower wet-weight, and flower dry-weight on different LOF dose treatment showed a highly significant difference, and the highest average was in the D3 treatment (75ml/plant). For the observation of harvest index, various doses of LOF showed a highly significant difference, and the highest average was in treatment D2 (50 $\mathrm{ml} / \mathrm{plant})$. However, it was not significantly different from $\mathrm{D} 4(100 \mathrm{ml} / \mathrm{plant})$.
\end{abstract}

Kata kunci : cauliflower, growth, yield, liquid organic fertilizer.

\section{PENDAHULUAN}

Tanaman kubis bunga atau juga dikenal dengan sebutan kembang kol (Brassica oleracea var. Botritis) adalah salah satu jenis sayuran yang sudah lama dikenal oleh masyarakat Indonesia. Sayuran ini sangat disukai karena rasa dan teksturnya serta kandungan gizi yang cukup tinggi. Dengan semakin berkembangnya tempat kuliner dan berbagai menu yang ditawarkan, permintaan komoditas ini pun semakin meningkat.

Kubis bunga memiliki bakal bunga yang mengembang dan membentuk massa bunga. Bunga tersebut berbentuk kerucut terbalik berwarna putih kekuningan (Taufan dan Hartatik, 2018). Beberapa kultivar yang dikenal adalah Snowball dan Winter. Agregat bunga pada kultivar Snowball bukanlah bunga yang sebenarnya tetapi pucuk-pucuk yang tidak berdiferensiasi. Sementara kultivar Winter memiliki bunga yang merupakan bunga yang sebenarnya.

Upaya peningkatan tanaman kubis bunga dapat dilakukan di antaranya adalah dengan intensifikasi, ekstensifikasi, diversifikasi, serta pemanfaatan pekarangan. Intensifikasi adalah peningkatan produksi melalui peningkatan potensi lahan dan produktifitas tanaman. Intensifikasi lahan pertanian dilakukan melalui pengolahan tanah, pengairan yang cukup, pemupukan yang tepat baik waktu dan jenisnya pengendalian hama dan penyakit serta menggunakan varietas unggul. Ekstensifikasi adalah peningkatan produksi tanaman dengan cara menambah luas lahan untuk penanaman tanaman kubis bunga. Keterbatasan luas lahan pertanian menjadi kendala dalam peningkatan produksi. Diversifikasi adalah meningkatkan keragaman tanaman pada suatu area pertanian misalnya dengan tumpangsari antara tanaman kubis bunga dengan tanaman sayuran lainnya atau tanaman palawija. Upaya lain yang bisa ditawarkan adalah dengan memanfaatkan pekarangan budidaya tanaman sayuran dengan menggunakan teknik vertikultur. Dalam upaya meningkatkan ketahanan pangan keluarga, salah satu program pemerintah dengan pemanfaatan pekarangan dengan tanaman sayuran melalui tanaman dalam pot secara vertikal, horizontal, ataupun dengan hidroponik. Di samping meningkatkan gizi keluarga, kelebihan produksi bisa menambah pendapatan keluarga (Artini et al., 2021)

Salah satu cara meningkatkan produksi tanaman kubis bunga melalui intensifikasi adalah dengan 
memperbaiki kesuburan tanah melalui pemupukan baik pupuk kimia (anorganik) atau pupuk hayati yang disebut juga pupuk organik. Pupuk hayati atau organik adalah pupuk yang dibuat dari bahan hayati seperti dekomposisi atau pelapukan dari limbah hewan, tumbuhan, dan manusia (Mulyono, 2017). Pupuk hayati atau pupuk organik dapat berbentuk padatan (seperti kompos) atau cair yang biasanya digunakan untuk meningkatkan kualitas tanah berupa sifat fisik, kimia, dan biologi tanah. Kelebihan pupuk organik di samping memperbaiki sifat fisik, kimia, dan biologi tanah juga bersifat aman untuk kesehatan tanah dan kesehatan manusia untuk mendapatkan produk organik pada tanaman kubis bunga.

Cara penggunaan pupuk organik cair (POC) sama dengan pupuk cair kimia dengan konsentrasi yang sangat rendah. Pupuk cair yang berasal dari pelindian sampah rumah tangga di samping dapat meningkatkan kesuburan tanah juga menguntungkan dalam pengelolaan sampah dan mengatasi polusi akibat penumpukan dan penyebaran penyakit yang mengganggu kesehatan manusia.

Pupuk organik cair (POC) yang memanfaatkan pelindian dari sampah dapur berupa limbah sisa sayuran setelah dilakukan penyiangan (Rainiyati et al., 2019). Dengan memanfaatkan mikroorganisme lokal (MOL) yang menempel pada daun bambu dan menggunakan nasi sebagai penangkapnya dapat dihasilkan fermentator (Lisanty dan Junaidi, 2021). Selanjutnya fermentator disemprotkan pada sisa sayuran tersebut akan menetes cairan hasil pelindian yang mengandung unsur hara. Cairan ini yang dimaksud dengan pupuk organik cair. Karena menggunakan fermentator MOL selanjutnya disebut dengan pupuk organik cair mikroorganisme lokal.

Meski demikian, belum diketahui dosis POC MOL yang tepat untuk tanaman kubis bunga sehingga menghasilkan pertumbuhan dan produksi maksimal. Penelitian dilakukan untuk mengetahui dosis POC MOL hasil pelindian sampah rumah tangga yang tepat, sehingga diperoleh laju pertumbuhan dan produksi maksimal. Hipotesis menduga bahwa dengan pemberian POC MOL dengan dosis $375 \mathrm{ml}$ per tanaman yang diberikan sebanyak 5 kali (masing-masing $75 \mathrm{ml} /$ tanaman) diperoleh produksi maksimal.

\section{BAHAN DAN METODE}

Penelitian dilakukan di greenhouse Fakultas Pertanian Universitas Kadiri di Kelurahan Pojok Kecamatan Mojoroto Kota Kediri Jawa Timur, dari tanggal 20 Juni 2021 sampai dengan 31 Agustus 2021.
Rancangan lingkungan dalam penelitian ini menggunakan Rancangan Acak Lengkap (RAL), dengan perlakuan faktor tunggal yaitu dosis pupuk organik cair mikroorganisme lokal (MOL), yang terdiri dari 6 taraf dan diulang 4 kali. Perlakuan dosis pupuk organik terdiri dari: D0 (tanpa pemupukan), D1 (dosis POC MOL 25 $\mathrm{ml} /$ pemberian/tanaman), D2 (dosis POC MOL 50 $\mathrm{ml} /$ pemberian/tanaman), D3 (dosis POC MOL 75 $\mathrm{ml} /$ pemberian/tanaman), D4 (dosis POC MOL 100 $\mathrm{ml} /$ pemberian/tanaman), D5 (dosis POC $125 \mathrm{ml}$ $\mathrm{MOL} /$ pemberian/tanaman). Setiap perlakuan dan ulangan terdiri dari dua polybag (duplo), selanjutnya menggunakan uji taraf dengan Uji Beda Nyata Terkecil (BNT 5\%). Interval pemberian pupuk organik cair MOL Pemberian pupuk organik cair (MOL) diberikan tujuh hari sekali sehingga sampai dengan fase generatif diberikan sebanyak lima kali.

Pelaksanaan penelitian dibedakan menjadi empat bagian yaitu persiapan penelitian, penanaman, pengamatan, dan perawatan. Persiapan penelitian dimulai dengan penyemaian benih sehingga diperoleh bibit yang siap dipindahtanam (transplanting). Penyemaian dilakukan pada kertas bungkus yang dipotong dengan ukuran $5 \times 15 \mathrm{~cm}$, dibuat pot penyemaian dengan tinggi $5 \mathrm{~cm}$. Pot penyemaian diisi dengan media dengan perbandingan tanah-kompos 1:1. Selanjutnya ditanami dengan benih kubis bunga satu biji per pot. Perawatan penyemaian dilakukan dengan penyiraman dan bibit bisa dipindahkan ke polibag setelah mempunyai 2 daun. Pemindahan semaian memerlukan polibag yang diisi dengan media campuran antara tanah-pupuk organik padat 1:2. sebanyak $4 \mathrm{~kg}$ per polibag. Bibit yang sudah siap dipindahkan ditanam pada media yang sudah dipersiapkan dengan satu bibit per media tanam. Dilakukan penanaman pada sore hari untuk menghindari masa stagnasi pada bibit.

Parameter pengamatan yang dilakukan sebelum masa generatif terdiri dari tinggi tanaman, jumlah daun, dan luas daun dilakukan dengan interval 7 hari sekali pada umur 9, 16, 23 dan 30 hari setelah tanam (HST). Pengukuran luas daun dengan menggunakan metode Panjang x Lebar $\mathrm{x}$ konstanta. Sedangkan parameter pengamatan yang dilakukan saat panen adalah berat basah akar, berat kering akar, berat basah tanaman, berat kering tanaman, berat basah bunga, dan berat kering bunga. Pengamatan berat kering digunakan untuk menentukan laju pertumbuhan (GR) dan Indeks Panen (HI).

Perawatan dilakukan dengan melakukan penyiraman, pemupukan dan pengendalian hama/penyakit. Penyiraman dilakukan dengan menggunakan alat penyiram secukupnya. Pemupukan menggunakan POC MOL sesuai dengan perlakuan dengan interval tujuh hari sekali 
sampai fase generatif (tumbuh bunga). Pengendalian hama dan penyakit dilakukan secara manual apabila terlihat ada gejala.

\section{HASIL DAN PEMBAHASAN}

\section{Tinggi Tanaman}

Berdasarkan hasil analisis ragam menunjukkan tidak terjadi perbedaan yang nyata pada pengamatan tinggi tanaman umur 9 HST dan berbeda nyata pada umur 16, 23 dan 30 HST dengan rata-rata tinggi tanaman disampaikan pada Tabel 1.

Tabel 1. Rata-rata Tinggi Tanaman $(\mathrm{cm})$ pada umur 9, 16, 23 dan 30 HST

\begin{tabular}{|c|l|l|l|l|}
\hline \multirow{3}{*}{ Perlakuan } & \multicolumn{4}{|c|}{ Rata-rata Tinggi Tanaman Umur } \\
\cline { 2 - 5 } & $9 \mathrm{HST}$ & $\begin{array}{c}16 \\
\text { HST }\end{array}$ & $\begin{array}{c}23 \\
\text { HST }\end{array}$ & $\begin{array}{c}30 \\
\text { HST }\end{array}$ \\
\hline Do & 16.00 & $15.00 \mathrm{a}$ & $26.12 \mathrm{a}$ & $27.35 \mathrm{ab}$ \\
D1 & 15.50 & $16.17 \mathrm{ab}$ & $27.00 \mathrm{~b}$ & $28.05 \mathrm{~b}$ \\
D2 & 14.50 & $16.12 \mathrm{ab}$ & $27.12 \mathrm{bc}$ & $28.37 \mathrm{~b}$ \\
D3 & 15.75 & $18.12 \mathrm{~b}$ & $28.75 \mathrm{c}$ & $30.00 \mathrm{c}$ \\
D4 & 15.50 & $17.00 \mathrm{~b}$ & $27.87 \mathrm{bc}$ & $29.00 \mathrm{~b}$ \\
D5 & 14.75 & $15.62 \mathrm{ab}$ & $26.50 \mathrm{a}$ & $26.87 \mathrm{a}$ \\
\hline BNT 5\% & NS & 1.44 & 0.87 & 0.87 \\
\hline
\end{tabular}

Keterangan : ns=tidak berbeda nyata. Huruf yang sama pada satu kolom menunjukkan rata-rata tersebut tidak berbeda nyata menurut uji Beda Nyata Terkecil dengan tingkat kepercayaan $95 \%$.

Pada rata-rata tinggi tanaman di atas menunjukkan bahwa pengamatan pada umur 9 HST tidak ada perbedaan yang nyata disebabkan pada umur tersebut tanaman kubis bunga masih kecil dan baru dipindahtanam sehingga kebutuhan unsur hara masih bisa dipenuhi oleh media tanam walaupun tidak dipupuk di samping masih mengalami stagnasi.

Pada pengamatan berikutnya yaitu umur 16, 23 dan 30 HST menunjukkan perbedaan yang sangat nyata dengan tanaman tertinggi pada pada perlakuan D3 (dosis $75 \mathrm{ml} /$ tanaman/pemberian pupuk). Hal ini disebabkan pada perlakuan pemupukan untuk pertumbuhan maksimal kubis bunga di dataran rendah. Temuan ini sejalan dengan penelitian Rovi'ati et al. (2019) bahwa selama masa vegetatif, tinggi tanaman kubis bunga akan terus bertambah. Tinggi tanaman berhenti bertambah sekitar setelah minggu ke-5 atau setelah memasuki masa generatif.

\section{Jumlah Daun}

Sesuai dengan hasil analisis ragam menunjukkan bahwa pada parameter jumlah daun tidak berbeda nyata pada pengamatan umur 9 HST dan berbeda sangat nyata pada pengamatan umur 16, 23 dan 30 HST (sama seperti pada pengamatan parameter tinggi tanaman, jumlah daun mempunyai pola yang sama yaitu tidak berbeda nyata pada pengamatan umur 9 HST) sebagaimana ditunjukkan pada Tabel 2 di bawah ini. Hal ini disebabkan pada umur tersebut ukuran daun maksimal masih bisa dipenuhi oleh kandungan unsur hara yang berada pada media tanaman, sehingga penambahan dengan yang diperlakukan tidak berbeda nyata.

Tabel 2. Rata-rata Jumlah Daun (helai) pada umur 9, 16, 23 dan 30 HST

\begin{tabular}{|c|c|c|c|c|}
\hline \multirow{3}{*}{ Perlakuan } & \multicolumn{4}{|c|}{ Rata-rata Jumlah Daun (helai) Umur } \\
\cline { 2 - 5 } & $9 \mathrm{HST}$ & $\begin{array}{c}16 \\
\text { HST }\end{array}$ & $\begin{array}{c}23 \\
\text { HST }\end{array}$ & $\begin{array}{c}30 \\
\text { HST }\end{array}$ \\
\hline Do & 4.87 & $7.87 \mathrm{a}$ & $10.63 \mathrm{a}$ & $10.63 \mathrm{a}$ \\
D1 & 4.89 & $10.13 \mathrm{~b}$ & $13.25 \mathrm{~b}$ & $13.25 \mathrm{~b}$ \\
D2 & 4.37 & $12.75 \mathrm{~cd}$ & $15.75 \mathrm{c}$ & $15.75 \mathrm{c}$ \\
D3 & 4.87 & $16.50 \mathrm{e}$ & $19.13 \mathrm{~d}$ & $19.13 \mathrm{~d}$ \\
D4 & 4.62 & $14.00 \mathrm{~d}$ & $18.37 \mathrm{~d}$ & $18.37 \mathrm{~d}$ \\
D5 & 4.37 & $11.50 \mathrm{c}$ & $15.13 \mathrm{c}$ & $15.13 \mathrm{c}$ \\
\hline BNT 5\% & NS & 1.40 & 1.47 & 1.65 \\
\hline
\end{tabular}

Keterangan : ns=tidak berbeda nyata. Huruf yang sama pada satu kolom menunjukkan rata-rata tersebut tidak berbeda nyata menurut uji Beda Nyata Terkecil dengan tingkat kepercayaan $95 \%$.

Sedangkan pengamatan rata-rata jumlah daun setelah umur 9 HST dijumpai adanya berbedaan yang sangat nyata dan jumlah terbanyak adalah pada perlakuan D3 (75 ml/tanaman) namun pada pengamatan umur 23 dan 30 HST tidak berbeda nyata dengan perlakuan D4 (100 ml/tanaman) dan D5 (125 ml/tanaman). Hal ini disebabkan pada umur tersebut kebutuhan tanaman untuk meningkatkan jumlah daun semakin bertambah sehingga perlakuan D4 yang semula lebih kecil dari D3 menjadi tidak berbeda nyata.

Berdasarkan penelitian Kustiani dan Saptorini (2019), seiring umur tanaman, kandungan unsur hara yang dibutuhkan tanaman juga bertambah. Unsur hara makro dan mikro yang tersedia cukup untuk tanaman umumnya dapat memacu pertumbuhan. Dalam hal ini, tinggi tanaman berkaitan erat dengan tangkai daun. Tanaman yang tinggi akan memiliki lebih banyak tangkai daun. Tangkai daun yang banyak berarti lokasi tumbuh dan jumlah daun yang lebih banyak juga pada tanaman.

\section{Luas Daun}

Luas daun pada tanaman kubis bunga ditentukan dengan metode Panjang x Lebar X konstanta. Dari hasil analisis ragam menunjukkan bahwa tidak ada perbedaan yang nyata pada pengamatan rata-rata luas daun umur 9 HST, namun berbeda sangat nyata pada umur pengamatan 16, 23 dan 30 HST. Lebih rinci mengenai rerata luas daun selama pengamatan ditampilkan pada Tabel 3.

Tabel 3. Rata-rata Luas Daun $\left(\mathrm{cm}^{2}\right)$ pada umur 9 , 16, 23 dan 30 HST

\begin{tabular}{|c|c|c|c|c|}
\hline \multirow[b]{2}{*}{ Perlakuan } & \multicolumn{4}{|c|}{ Rata-rata Luas Daun $\left(\mathrm{cm}^{2}\right)$ Umur } \\
\hline & 9 HST & $\begin{array}{c}16 \\
\text { HST }\end{array}$ & $\begin{array}{c}23 \\
\text { HST }\end{array}$ & $\begin{array}{c}30 \\
\text { HST }\end{array}$ \\
\hline Do & 15.80 & $109.20 \mathrm{ab}$ & $118.50 \mathrm{a}$ & $119.30 \mathrm{a}$ \\
\hline D1 & 16.80 & $122,50 \mathrm{ab}$ & $122.60 \mathrm{ab}$ & $124.80 \mathrm{a}$ \\
\hline D2 & 18.60 & $126.70 \mathrm{~b}$ & $136.30 \mathrm{~b}$ & $130.40 \mathrm{~b}$ \\
\hline D3 & 19.80 & $145.40 \mathrm{c}$ & $157.40 \mathrm{c}$ & $159.60 \mathrm{c}$ \\
\hline D4 & 19,30 & $126.70 \mathrm{~b}$ & $139.90 \mathrm{~b}$ & $141.90 \mathrm{~b}$ \\
\hline D5 & 15.40 & $108.30 \mathrm{a}$ & $124.00 \mathrm{ab}$ & $126.10 \mathrm{a}$ \\
\hline BNT 5\% & Ns & 17.82 & 14.70 & 7.08 \\
\hline
\end{tabular}


Keterangan : ns=tidak berbeda nyata. Huruf yang sama pada satu kolom menunjukkan rata-rata tersebut tidak berbeda nyata menurut uji Beda Nyata Terkecil dengan tingkat kepercayaan $95 \%$.

Pada umur tanaman 9 HST, tinggi tanaman dan jumlah daun belum membutuhkan tambahan unsur hara untuk pertumbuhan, sehingga pada luas daun mempunyai pola yang sama yaitu cukup dengan hara pada media tanah awal.

Luas daun terbesar terdapat pada perlakuan D3 (75 $\mathrm{ml} /$ tanaman) dan berbeda dengan yang lainnya. Hal ini disebabkan pada dosis tersebut menyebabkan tanaman tinggi dan jumlah daunnya banyak sehingga sangat mendukung untuk pertambahan luasan.

Menurut Kustiani (2018), tanaman dengan pertumbuhan yang baik (tinggi) dan banyak memiliki jumlah daun disertai beragam kondisi longgar akan menyebabkan terciptanya peluang untuk proses fotosintesis dan respirasi yang baik juga. Hal ini berakibat pada terbentuknya daun yang ukurannya lebih luas.

\section{Rata-rata Berat Basah dan Berat Kering Akar}

Sesuai dengan hasil analisis ragam menunjukkan bahwa perlakuan dosis POC MOL berbeda sangat nyata terhadap rata-rata berat basah dan berat kering akar pada saat panen. Tabel 4 menyajikan rerata berat basah dan kering akar tanaman dalam satuan gram saat panen dilakukan.

Tabel 4. Rata-rata Berat Basah dan Berat Kering Akar Tanaman (gram) Saat Panen

\begin{tabular}{|c|c|c|}
\hline \multirow{2}{*}{ Perlakuan } & \multicolumn{2}{|c|}{ Bobot Akar (Gram) } \\
\cline { 2 - 3 } & Berat Basah & Berat Kering \\
\hline Do & $5.09 \mathrm{a}$ & $1.29 \mathrm{a}$ \\
D1 & $5.43 \mathrm{ab}$ & $2.00 \mathrm{a}$ \\
D2 & $8.14 \mathrm{~b}$ & $2.07 \mathrm{a}$ \\
D3 & $12.59 \mathrm{c}$ & $5.68 \mathrm{~b}$ \\
D4 & $7.48 \mathrm{ab}$ & $2.16 \mathrm{a}$ \\
D5 & $6.40 \mathrm{ab}$ & $1.64 \mathrm{a}$ \\
\hline BNT 5\% & 2.75 & 8.68 \\
\hline
\end{tabular}

Keterangan: ns: tidak berbeda nyata. Huruf yang sama pada satu kolom menunjukkan rata-rata tersebut tidak berbeda nyata menutut uji Beda Nyata Terkecil dengan tingkat kepercayaan $95 \%$.

Rata-rata berat basah dan berat kering akar tertinggi pada perlakuan D3 (75 ml per tanaman). Hal ini disebabkan pada perlakuan tersebut tanaman mempunyai daun yang luas, tanamannya tinggi, dan jumlah daunnya banyak sehingga akumulasi bahan akibat fotosintesis (akumulasi hasil metabolisme menjadi lebih besar). Dengan demikian terbentuk tanaman yang lebih besar dan berat termasuk bahan keringnya. Menurut Annisa et al. (2018), pertumbuhan tanaman yang baik akan diiringi juga dengan penambahan bobot kering pada tanaman tersebut.

\section{Berat Basah dan Berat Kering Tanaman}

Berdasarkan hasil analisis ragam menunjukkan bahwa berat basah dan berat kering tanaman menunjukkan perbedaan sangat nyata. Perlakuan D3 merupakan rata-rata berat basah dan berat kering tanaman yang tertinggi. Dengan jumlah daun, tinggi tanaman, dan luas daun yang tertinggi pada perlakuan D3 menyebabkan tanaman tersebut

Tabel 5. Rata-rata Berat Basah dan Berat Kering Tanaman (gram) Saat Panen

\begin{tabular}{|c|c|c|}
\hline \multirow{2}{*}{ Perlakuan } & \multicolumn{2}{|c|}{ Bobot Tanaman (Gram) } \\
\cline { 2 - 3 } & Berat Basah & Berat Kering \\
\hline Do & $129.90 \mathrm{a}$ & $10.36 \mathrm{a}$ \\
D1 & $125.30 \mathrm{ab}$ & $12.26 \mathrm{ab}$ \\
D2 & $181.50 \mathrm{c}$ & $17.44 \mathrm{c}$ \\
D3 & $218.90 \mathrm{~d}$ & $21.79 \mathrm{~d}$ \\
D4 & $191.50 \mathrm{c}$ & $18.63 \mathrm{c}$ \\
D5 & $135.00 \mathrm{~b}$ & $13.68 \mathrm{~b}$ \\
\hline BNT 5\% & 23.55 & 2.04 \\
\hline
\end{tabular}

Keterangan : ns=tidak berbeda nyata. Huruf yang sama pada satu kolom menunjukkan rata-rata tersebut tidak berbeda nyata menurut uji Beda Nyata Terkecil dengan tingkat kepercayaan $95 \%$.

mempunyai brangkasan terbesar. Kustiani et al. (2021) berpendapat bahwa dosis pupuk berpengaruh terhadap berat basah dan kering tanaman.

\section{Berat Basah dan Berat Kering Bunga}

Dari hasil analisis ragam menunjukkan bahwa perlakuan dosis POC MOL berpengaruh sangat sangat nyata, terhadap berat basah dan berat kering kubis bunga.

Tabel 6. Rata-rata Berat Basah dan Berat Kering Tanaman (gram) Saat Panen

\begin{tabular}{|c|c|c|}
\hline \multirow{2}{*}{ Perlakuan } & \multicolumn{2}{|c|}{ Bobot Bunga / Tanaman (Gram) } \\
\cline { 2 - 3 } & Berat Basah & Berat Kering \\
\hline Do & $66.26 \mathrm{a}$ & $7.07 \mathrm{a}$ \\
D1 & $97.93 \mathrm{~b}$ & $11.72 \mathrm{~b}$ \\
D2 & $138.28 \mathrm{c}$ & $13.60 \mathrm{~b}$ \\
D3 & $178.70 \mathrm{~d}$ & $18.53 \mathrm{c}$ \\
D4 & $145.53 \mathrm{c}$ & $13.40 \mathrm{~b}$ \\
D5 & $115.75 \mathrm{~b}$ & $11.79 \mathrm{~b}$ \\
\hline BNT 5\% & 23.77 & 3.29 \\
\hline
\end{tabular}

Keterangan : ns=tidak berbeda nyata. Huruf yang sama pada satu kolom menunjukkan rata-rata tersebut tidak berbeda nyata menurut uji Beda Nyata Terkecil dengan tingkat kepercayaan 95\%.

Pola berat basah dan berat kering pada pada parameter pengamatan berat basah dan berat kering bunga sesuai dengan pertumbuhan berat basah dan berat kering akar dan tanaman.

\section{Indeks Panen}

Indeks panen bukan merupakan hasil panen tertinggi, melainkan merupakan gambaran pembagian akumulasi hasil fotosintesis yang diakumulasikan ke produksi. Sesuai dengan hasil analisis ragam menunjukkan bahwa perlakuan dosis POC MOL berbeda sangat nyata dan indeks panen tertinggi pada perlakuan D2. Hal ini disebabkan 
bahwa alokasi hasil asimilasi lebih besar diarahkan pada pembentukan bunga walaupun ukuran bunganya lebih kecil jika dibandingkan dengan perlakuan lain (Luthfiana et al., 2019).

Tabel 7. Rata-rata Indeks Panen (HI) Tanaman Kubis Bunga Saat Panen

\begin{tabular}{|c|c|}
\hline Perlakuan & Indek Panen \\
\hline Do & $0.38 \mathrm{a}$ \\
D1 & $0.44 \mathrm{a}$ \\
D2 & $0.46 \mathrm{~b}$ \\
D3 & $0.39 \mathrm{a}$ \\
D4 & $0.45 \mathrm{ab}$ \\
D5 & $0.45 \mathrm{~b}$ \\
\hline BNT 5\% & 0.06 \\
\hline
\end{tabular}

Keterangan : ns=tidak berbeda nyata. Huruf yang sama pada satu kolom menunjukkan rata-rata tersebut tidak berbeda nyata menurut uji Beda Nyata Terkecil dengan tingkat kepercayaan $95 \%$.

\section{KESIMPULAN}

Berdasarkan analisis data dapat disimpulkan:

1 Dosis pupuk organik cair (MOL) tidak berpengaruh nyata pada pengamatan tinggi tanaman, jumlah daun, dan luas daun pada umur 9 HST.

2 Dosis pupuk organik cair (MOL) berpengaruh sangat nyata pada tinggi tanaman, jumlah daun, dan luas daun umur 16, 23 dan 30 HST dan rata-rata tertinggi pada perlakuan D3 (75ml/pemberian/tanaman).

3 Dosis pupuk organik cair (MOL) berpengaruh sangat nyata terhadap berat basah akar, berat kering akar, berat basah, dan berat kering tanaman. Rata-rata tertinggi pada perlakuan D3 (75 $\mathrm{ml} /$ pemberian/tanaman.)

4 Perlakuan dosis pupuk organik cair (MOL) berpengaruh nyata terhadap pengamatan indeks panen (HI) dan rata-rata tertinggi pada perlakuan D2 (50 $\mathrm{ml} /$ pemberian/tanaman).

\section{UCAPAN TERIMA KASIH}

Terima kasih penulis ucapkan kepada LP3M Universitas Kadiri yang telah membiayai penelitian ini. Ucapan terima kasih selanjutnya disampaikan kepada rekan sejawat di Fakultas Pertanian Universitas Kadiri yang telah membantu penelitian dan penyusunan artikel penelitian ini.

\section{DAFTAR PUSTAKA}

Annisa D, Darmawati A, dan Sumarsono. 2018. Pertumbuhan dan produksi bayam merah (Amaranthus tricolor L.) dengan pemberian pupuk kandang dan giberelin. J. Agro Complex, Volume: 2 No: 2, Hal: 102-108.
Artini W, Sidhi E Y, Ghofiliani G S. 2021. Membangun Budaya Bertani pada Remaja untuk Mendukung Ketahanan Pangan Keluarga di Desa Nglaban Kecamatan Loceret Kabupaten Nganjuk. Jatimas: Jurnal Pertanian dan Pengabdian Masyarakat. Volume: 1 No: 1 Hal: 66-74

Kustiani E. 2018. Aplikasi Pupuk Organik Cair (Urin Sapi) dan Populasi pada Kangkung Darat (Ipomoea reptans Poir.). Jurnal Agrinika: Jurnal Agroteknologi dan Agribisnis. Volume: 2 No: 2 Hal: 103-114

Kustiani E, Mariyono, dan Ayuningtyas B E. 2021. Respon Pertumbuhan dan Hasil Tanaman Bayam Merah (Amaranthus gangeticus) pada Perlakuan Dosis Pupuk ZA. Jurnal Agrinika: Jurnal Agroteknologi dan Agribisnis. Volume: 5 No: 2 Hal: 180-188

Kustiani E dan Saptorini. 2019. Optimalisasi Dosis Pupuk Organik Cair Mikroorganisme Lokal terhadap Pertumbuhan Sawi Daging. Jurnal Agrinika: Jurnal Agroteknologi dan Agribisnis. Volume: 3 No: 1 Hal: 16-28

Lisanty N dan Junaidi. 2021. Produksi Pupuk Organik Cair (POC) dengan Memanfaatkan Mikro Organisme Lokal (MOL) di Desa Jegreg Kabupaten Nganjuk. Jatimas: Jurnal Pertanian dan Pengabdian Masyarakat. Volume: 1 No: 1 Hal: 1-10

Luthfiana A L G, Haryono, dan Histiriawati. 2019. Hasil Tanaman Kubis Bunga (Brassica oleracea var botritis L.) pada Jarak Tanam dan Mulsa Organik. VIGOR: Jurnal Ilmu Pertanian Tropika dan Subtropika. Volume: 4 No: 1 Hal: 18-23

Mulyono. 2017. Membuat Mikroorganisme Lokal (MOL) dan Kompos dari Sampah Rumah Tangga. Agromedia Pustaka Utama. Jakarta.

Rainiyati A, Zulkarnain R, Eliyanti S, Heraningsih F. 2019. Pemanfaatan Sampah Rumah Tangga Menjadi Beberapa Jenis Pupuk Organik Cair MOL (Mikroorganisme Lokal) di Desa Pudak Kecamatan Kumpeh Ulu Kabupaten Muara Jambi. Jurnal Pengabdian Masyarakat Volume: 4 No: 4 Hal: 555-562

Rovi'ati A, Muliawati E S, dan Harjoko D. 2019. Respon Kembang Kol dataran Rendah Terhadap Kepekatan Nutrisi pada Floating Hydroponic system Termodifikasi. Agrosains. Volume: 21 No: 1 Hal: 11-15

Taufan Y P, dan Hartatik S. 2018. Respon Pertumbuhan dan Hasil Beberapa Varietas Bunga Kol (Brassica oleracea) var. Botritis terhadap Penggunaan Pupuk Majemuk N, P, K di Dataran Rendah. Seminar Nasional Agribisnis Fakultas Pertanian Universitas Jember 03 November 2018. 